\title{
An Analysis of the Prospectus Regime: The EU Reforms and the 'Brexit' Factor Elizabeth Howell*
}

\section{Introduction}

Amidst the continuing chaos flowing from the UK's epochal decision to leave the EU, it might be queried why the UK's prospectus regime merits consideration. It is certainly not at the top of the British government's list of negotiating priorities, and tapping the capital markets can be regarded as a rather outmoded means of raising finance, particularly given the increasing number of alternative finance options that have sprung up over the years for budding start-up companies, from crowdfunding to initial coin offerings. ${ }^{1}$ Yet, facilitating access to market-based finance for firms remains a hot topic. For instance, as part of its wider Capital Markets Union programme, the EU recently revamped its prospectus regime, with the specific intention of making it easier for issuers to access and raise funds, via the public markets. $^{2}$ Indeed, mirroring the approach being taken across the Atlantic in the US, there is a clear de-regulatory flavour to the new EU rules that seek to simplify prospectus law for all companies, and to alleviate the burden on small companies drawing up prospectuses. ${ }^{3}$ Moreover, at the UK level, it is notable that London is also currently competing with New York to try and attract a major stock market listing concerning part of Saudi Arabia's national oil company, Saudi Aramco. Linked to this, the UK regulator, the Financial Conduct Authority (the ' $F C A^{\prime}$ '), is contemplating what could be a questionable watering down of its listing requirements for state-owned companies seeking access to the premium segment of the UK's public markets, which has raised the question in some quarters as to whether politicians could be placing pressure on regulators to endorse the pulling power of the City of London in the light of 'Brexit'. ${ }^{4}$

Regardless of one's views on Saudi Aramco, what is certainly clear is that Brexit creates significant new challenges; it risks placing the UK's position as a leading financial and capital markets centre in jeopardy, and it places existing, long-established market access arrangements in doubt. ${ }^{5}$ Yet, it is also the case that the UK could have the ability going

\footnotetext{
* Slaughter and May Lecturer in Corporate Law, Faculty of Law, Cambridge. I am grateful to the ECFR referees for their valuable comments. The paper has also benefitted from feedback following a presentation at a Cambridge Law Faculty workshop in November 2017. The usual disclaimers apply.

${ }^{1}$ Indeed, in this regard, the number of firms engaging in initial public offerings that require the production of approved prospectuses declined considerably during the global financial crisis, and since then the numbers have continued to drop, but a slower pace, see further, ESMA, EEA Prospectus Activity in 2016 (2017).

2 European Commission, Action Plan on Building a Capital Markets Union COM(2015) 468 Final (2015) 12; Regulation (EU) 2017 on the Prospectus to Be Published When Securities Are Offered to the Public or Admitted to Trading on a Regulated Market, and Repealing Directive 2003/71/EC.

${ }^{3}$ For a comprehensive and critical analysis of the de-regulatory shifts occurring in the US, see e.g. Merritt Fox, 'Regulating Public Offerings of Truly New Securities: First Principles' (ECGI Working Paper No 338/2017).

4 Business Leader, 'Aramco May Be Big, but Fawning to Saudis Diminishes London' The Guardian (16 July 2017); Financial Conduct Authority, Proposal to Create a New Premium Listing Category for Sovereign Controlled Companies: Consultation Paper 17/21 (2017).

${ }^{5}$ See Oliver Wyman, Strengthening Europe's Position in Global Capital Markets (2017).
} 
forward, should it so wish, to extricate itself from the EU's prospectus regime. Indeed, the UK is especially well-equipped in this regard, given the dominant role it plays in global and EU capital markets, and given that, historically, the UK has been closely involved with, and a key influence in the design of EU regulations, both with respect to capital markets, and more generally in relation to financial regulation. ${ }^{6}$

Accordingly, with a view to a greater understanding of the road that the UK is now embarking upon, this paper contributes to the existing legal scholarship on prospectuses and considers what could, or should, happen to the UK's prospectus regime following Brexit. Indeed although it remains unclear what Brexit is going to look like, or what the implications will be with respect to the UK's financial services industry more generally, ${ }^{7}$ this paper examines the EU's prospectus regime and then considers three possible prospects for the UK with respect to a future prospectus framework, premised on the basis that the UK will leave the single market when it exits the EU.

The first, and most straightforward route, at first blush, would be to adopt EU law wholesale, as is currently proposed by the UK's government. ${ }^{8}$ In principle, this could mean that the existing EU prospectus regime would continue to apply in the UK, as would the new EU provisions, when the bulk of these take effect in July 2019. The devil is in the detail, however, not least with the technicalities surrounding the conversion of EU law into domestic law, and with respect to the complex questions that could arise with respect to 'third country' equivalence determinations that would allow such a prospectus to be approved for an offer or listing on a regulated market in the EU. Further, such technical questions could also risk becoming political, particularly in the light of the fraught nature of the Brexit negotiations, even when one factors in the important contributions in this area of securities law by the technocrat, the European Securities and Markets Authority ('ESMA')). ${ }^{9}$

The second option would be more ambitious; in line with the regulator's interest in rolling out the red carpet for a prospective Saudi Aramco flotation, such a model would involve more of a 'regulatory bonfire': with a new bespoke UK prospectus and listing regime being particularly geared towards attracting international business to list in London. ${ }^{10}$ Yet, although such a notion may seem attractive, especially politically to hard-line 'Brexiteers', this paper advocates a third option. Specifically, as will be argued, the true strength of a prospectus regime derives from the provision of full and accurate disclosure to rational investors ex ante. This information enables sophisticated market participants to accurately price an initial public offer ('IPO'), and this then also indirectly protects any retail investors that are purchasing shares. ${ }^{11}$ Aspects of the new EU prospectus reforms, with their deregulatory focus, risk coming into conflict with these aims, and such provisions may also

\footnotetext{
${ }^{6}$ See further e.g. Eilís Ferran, Building an EU Securities Market (Cambridge University Press 2004).

${ }^{7}$ See further e.g. John Armour, 'Brexit and Financial Services' (2017 (forthcoming)) Oxford Review of Economic Policy (Brexit Special Issue).

${ }^{8}$ European Union (Withdrawal) Bill 2017, clause 2.

${ }^{9}$ For instance, under the existing EU prospectus regime, ESMA has produced a framework for third country prospectuses, and provided opinions with respect to Turkish, and Israeli laws on prospectuses, see e.g. ESMA, Framework for the Assessment of Third Country Prospectuses under Article 20 of the Prospectus Directive (ESMA/2013/317).

${ }^{10}$ See e.g. 'Brexit Is a Golden Chance to Throw Some EU Regulations on a Bonfire' The Telegraph (28 March 2017).

${ }^{11}$ Luca Enriques, EU Prospectus Regulation: Some Out-Of-The-Box Thinking (May 2016).
} 
be unpopular with issuers and their advisers as they could increase the risk of subsequent civil litigation. Accordingly, the third route that the paper proposes would involve the UK continuing with a regulatory approach it has oft embraced in the past, of 'gold plating' EU regulations. ${ }^{12}$ In this regard, applying and bolstering the EU provisions, where required, may be more likely to guarantee the prospectus serves as a valuable investor protection device, as well as offering an attractive fundraising vehicle for firms, which can serve to lower companies' cost of capital.

This article is structured as follows. Following this introduction, part 2 provides a broad overview of the prospectus's purpose. Part 3 sets out the general framework and thinking behind the rules requiring mandatory disclosure via a prospectus. Part 4 applies this framework to two discrete de-regulatory aspects of the revised EU regime that may come into conflict with traditional arguments that champion full prospectus disclosure. Part 5 then draws on the foregoing analysis to examine the state of play for the UK with respect to Brexit. The EU regime is used as the starting point for this analysis and three potential policy avenues are examined for future UK models. The article advocates a gold plated approach and speculates that this is most likely to uphold the high standards of accuracy for which UK prospectuses have been historically renowned. Part 6 summarises.

\section{Why is a Prospectus Required?}

This article considers the prospectus regime through the lens of a UK company conducting a simple offer of shares to the public, where those shares are to be admitted to trading on a public securities market. ${ }^{13}$ This is a heavily regulated method of raising finance, partly due to the sums of money that can be involved, but also due to whom the offer may be aimed. For instance, on a large IPO (a term often used interchangeably in market parlance with 'flotation', 'listing' or 'coming to market'), involving a household name, a company may wish to market its offer not only to sophisticated market participants but also to the more vulnerable retail public.

An IPO is as an important step up the funding escalator for a firm: it is a watershed moment in a company's life. Up until this point, a company may have been running its business largely as its insiders wish; there may be only a small number of shareholders and directors; and there will be no requirements to announce either its successes or failures to the wider world. This changes irrevocably on an IPO, and a number of important consequences follow.

First, a flotation (especially on a high profile market) can raise substantial finance for a company and create a much broader, more dispersed, shareholder base, thereby facilitating a more liquid market for the buying and selling of shares, and enabling an easy exit for shareholders wishing to sell out. Further, an IPO can enhance a company's prestige; it is a sign of adulthood for a firm. Yet, there are costs. Aside from the considerable time, effort,

\footnotetext{
${ }^{12}$ Eilis Ferran, 'The UK as a Third Country Actor in EU Financial Services Regulation' (2017) 3 Journal of Financial Regulation and Compliance 40.

${ }^{13}$ Although there are a range of different methods for a company to raise finance from public investors, the focus of this paper is an orthodox public offer, where the shares on offer will be also admitted to trading on a public securities market (such as the Main Market of the London Stock Exchange). Note that the term 'securities' can include non-equity securities such as bonds, but the paper's focus is particularly with respect to a public offer of shares.
} 
and expense involved in preparing for an IPO, ${ }^{14}$ which will likely also involve a comprehensive overhaul and reorganisation of the company's structure and corporate governance set-up, a listed company will subsequently be subject to an extra (and continuing) layer of regulatory obligations as well as far greater market scrutiny from, amongst others, its investors, market analysts, and the financial press.

In line with this, one of the key legal consequences stemming from a company's decision to 'go public' on the main securities markets is the requirement to prepare and publish a prospectus. Specifically, a company wishing to tap the main capital markets for funds is obliged to disclose a host of information to its prospective investors, including providing a comprehensive story about the company and its business, as well as with respect to the shares on offer. Why is it required? From the issuer's perspective, the prospectus is a legal requirement, and it should, if well drafted, help protect it against the threat of any subsequent litigation: a type of liability shield. But it is also an important marketing and fundraising document: part of a carefully crafted story that should assist in selling its securities to prospective investors. From the regulator's standpoint, however, the main objectives of the prospectus regime are to ensure investor protection and market efficiency; it should contain the information necessary for investors to make an informed decision; and it should facilitate the widest possible access to capital markets by companies across the EU. ${ }^{15}$ More specifically, the precise aims with respect to investor protection can be broken down into two main elements: first, prospective investors should be entitled to full disclosure of information in order to decide whether to buy shares and make efficient resource allocation decisions. ${ }^{16}$ Second, at the remedies end, a prospectus liability regime should provide compensation to those who have suffered loss due to misstatements, and it should also deter the making of misstatements in the first place. ${ }^{17}$

Applying this to the law: in the EU, the first element, the prospectus disclosure requirements, have been harmonised since 2003; the theoretical framework of which will be examined in section 3. With respect to the second regulatory element, however, of investor remedies, despite an increasing emphasis towards ensuring supervisory convergence in recent years, ${ }^{18}$ these rules have never been harmonised in a meaningful way, nor do they articulate the applicable civil liability regime. ${ }^{19}$ Although this is for a number of perfectly understandable reasons, including a lack of agreement between different jurisdictions with

\footnotetext{
${ }^{14}$ Estimates vary but costs can be approximately between 3 and 15 per cent of the amount raised depending on the magnitude of the IPO, European Commission, Impact Assessment Accompanying Prospectus Regulation Proposal SWD(2015) 255 Final (2015).

${ }^{15}$ European Commission, Review of the Prospectus Directive: Consultation (February 2015).

${ }^{16}$ This should further the interests of investors, the companies, and of the economy; it should ensure the allocation of investment resources to the most deserving projects.

${ }^{17}$ Louise Gullifer and Jennifer Payne, Corporate Finance Law: Principles and Policy (2nd edn, Hart 2015) chapter 10.

${ }^{18}$ See e.g. ESMA, Supervisory Convergence: Work Programme (2017).

${ }^{19}$ Prospectus Regulation, art 11(2) simply provides that Member States shall ensure that their laws on civil liability apply to those persons responsible for the information given in the prospectus. See also ESMA, Comparison of Liability Regimes in Member States in Relation to the Prospectus Directive (2013/619).
} 
respect to the legal basis for such claims, ${ }^{20}$ an investor's actual level of protection will depend on the applicable law, as well as related procedural factors including ease of access to the courts. Issuers may also be reluctant to passport their prospectus into other jurisdictions due to the risk they could face claims in a number of Member States.

Linked to the provision of remedies on the law books, the level of enforcement intensity is important. ${ }^{21}$ On the public side, the regulator has a wide range of enforcement tools at its disposal (both administrative and criminal), and on the private side, a firm may face civil claims from investors who have incurred a loss. Although there is considerable debate as to whether private or public enforcement is the more important in the development of strong stock markets, ${ }^{22}$ private enforcement can have a role to play, and one that has been, until recently, underutilised in the UK, where, historically there have been extremely low levels of civil claims. The times change, however. Today, in a shift also observable beyond securities laws, it is now easier for investors throughout the EU to bring collective civil actions. ${ }^{23}$ For instance, the recent high profile case brought by the Royal Bank of Scotland's shareholders' against the bank and its directors, which settled at the eleventh hour, is a notable development with respect to investors seeking compensation for misleading statements via the prospectus liability regime. ${ }^{24}$ Accordingly, this may witness the start of a trend in investors embracing civil litigation in order to seek redress going forward. ${ }^{25}$ In the event there is an uptick, this can create a number of new challenges (including with respect to the risk of abuse), ${ }^{26}$ but it can also signal to other firms that there is a greater risk of subsequent

${ }^{20}$ Wolf-Georg Ringe and Alexander Hellgardt, 'The International Dimension of Issuer LiabilityLiability and Choice of Law from a Transatlantic Perspective' (2011) 31 Oxford Journal of Legal Studies 23.

${ }^{21}$ John Coffee, 'Law and the Market: The Impact of Enforcement' (2007) 156 University of Pennsylvania Law Review 229.

${ }^{22}$ See further Rafael La Porta, Florencio Lopez-de-Silanes and Andrei Schleifer, 'What Works in Securities Laws?' (2006) 61 J Fin 1; Howard Jackson and Mark Roe, 'Public and Private Enforcement of Securities Laws: Resource-Based Evidence' (2009) 93 Journal of Financial Economics 207; Eilis Ferran, 'Cross--Border Offers of Securities in the EU: The Standard Life Flotation' (2007) 4 ECFR 461.

${ }^{23}$ See Commission Recommendation on Common Principles for Injunctive and Compensatory Collective Redress Mechanisms in the Member States Concerning Violations of Rights Granted under Union Law (2013/396/EU); U.S. Chamber Institute for Legal Reform, The Growth of Collective Redress in the EU: A Survey of Developments in 10 Member States (2017).

${ }^{24}$ See e.g. Emma Dunkley, 'RBS and Retail Investors Reach $f 200 m$ Rights Issue Settlement' The Financial Times (6 June 2017)

${ }^{25}$ Note that similar shifts are also observable in the field of secondary market enforcement. In the UK, the regulator recently embraced its power to require Tesco, the supermarket giant, to pay compensation to investors with respect to a market update that gave a false or misleading impression. Yet the regulator's action does beg the question how far it should be using its relatively limited resources to further (often major) shareholder interests when there is now much easier access for aggrieved shareholders to pursue their claim directly in court, see further Neil Swift, Tesco Stores Limited: Restitution Arising out of Market Abuse (Oxford Business Law Blog) (2017).

${ }^{26}$ Reinier Kraakman and others, The Anatomy of Corporate Law: A Comparative and Functional Approach (3rd edn, OUP 2017) (n 26) chapter 9. Particularly with respect to the US, where securities litigation is far more prevalent, see John Coffee, 'Reforming the Securities Class Action: An Essay on Deterrence and Its Implementation' (2006) 106 Columbia Law Review 1534; Michael Klausner, 'Personal Liability of Officers in US Securities Class Actions' (2009) 9 Journal of Corporate Law Studies 349. 
enforcement action, thereby helping to ensuring prospectuses are accurate in the first place. ${ }^{27}$

\section{Prospectus Disclosure}

\subsection{Overview}

Why is prospectus disclosure the regulatory tool of choice in this area of the law? ${ }^{28}$ Certainly, disclosure is the strategy most utilised by regulators worldwide today, but one alternative, often termed merit-based regulation continues to apply to a limited extent, although this does vary from market to market. ${ }^{29}$ Considering the UK's position, in advance of an IPO, the regulator must approve a company's prospectus prior to publication and it can refuse an application where this would be detrimental to the interests of investors. ${ }^{30} \mathrm{In}$ theory, this could enable a regulator to, for instance, review the merits of a particular company's business with respect to taking a view on whether it could be detrimental to investors' interests. In practice, however, the UK regulator tends to be more of a general reviewer 'with the eye of an intelligent reader' who will identify key inaccuracies, ${ }^{31}$ rather than performing a role as a type of formal gatekeeper to the public markets. Hence although it is extremely unlikely that a prospectus would ever be approved where the insiders had expressly included their plan to 'run-off with the proceeds', ${ }^{32}$ a regulator is more likely to require a company to rectify any inaccuracies or defects than engaging in any value judgments about a particular business. ${ }^{33}$

Next, and specifically focusing on the UK, additional eligibility requirements also apply to applicants via the listing rules. In particular, extra quality controls are imposed on firms applying for a top-tier premium listing in the UK. ${ }^{34}$ Companies seeking such a listing are required to comply with additional domestic provisions on top of the minimum ('standard')

\footnotetext{
${ }^{27}$ Eilis Ferran, 'Cross-Border Offers of Securities in the EU: The Standard Life Flotation' (n 22).

${ }^{28}$ Note that for an examination of the evolution of disclosure regulation in the $19^{\text {th }}$ Century, including with respect to prospectus disclosure, see Carsten Gerner-Beuerle, 'Law and Finance in Emerging Economies: Germany and Britain 1800-1913' (2017) 80 Modern Law Review 263,
}

${ }^{29}$ See e.g. Reinier Kraakman and others chapter 9, who refer to this as a type of 'governance strategy'. See also SEC, Report on the Uniformity of State Regulatory Requirements for Offerings of Securities That Are Not "Covered Securities" (October 1997) with respect to the relatively limited role that merit review now plays in the US at the state level, and that disclosure is now the main strategy following its adoption at the federal level in the 1930s.

${ }^{30}$ Financial Services and Markets Act 2000, s75(5).

${ }^{31}$ See further, FSA, The Failure of the Royal Bank of Scotland: Financial Services Authority Board Report (2011), Appendix 2B.

${ }^{32}$ Gower: Principles of Modern Company Law (Paul L. Davies and Sarah Worthington eds, 10th edn, Sweet \& Maxwell 2016) chapter 25, referencing the ironic comments made by a committee of the Toronto Stock Exchange.

${ }^{33}$ In this regard see e.g. $R$ (on the Application of Yukos Oil Co and Another) $v$ Financial Services Authority and Another [2006] EWHC 2044 (admin) which involved a failed judicial review challenge to the regulator's decision to approve a prospectus relating to a controversial Russian listing with the judge (drawing on the comments of Sir Thomas Bingham MR) observing that courts should not 'second guess' the decisions of regulators. See also Gullifer and Payne (n 17) chapter 10.

${ }^{34}$ See in particular Listing Rules, chapter 6. 
listing rules that stem from the EU rules. ${ }^{35}$ Such premium listing requirements include a distinct policy emphasis on ensuring that prospective issuers are of a particular calibre, and specify provisions including in relation to a firm's trading history and the production of published accounts. ${ }^{36}$ Many of the premium listing requirements also extend beyond the listing application, and focus on on-going corporate governance obligations to be complied with once the firm is listed and trading.

Aside from this, specific information requirements in the prospectus may be also subject to various third party verification procedures. For instance, a company is required to include audited historical financial information in its prospectus covering the last three years; equally, if a company chooses to provide profit forecasts then it must contain a report by independent accountants or auditors that this has been properly compiled on the basis stated in the forecast, and is in accordance with the company's accounting policies. ${ }^{37}$ This verification process serves as an important check on the company's future expectations, especially given that companies will be keen to paint their future prospects in a positive light, ${ }^{38}$ and due to the fact that such projections could be given undue weight by investors. Further, other, so-called 'information intermediaries' will be involved on the IPO process. On a premium listing, such parties will include the sponsor (generally an investment bank) whose role will be to guide an applicant through the flotation, and who can certify and verify that the information being provided by the company is correct. Although this mechanism is not conflict-free, as the investment bank will be paid for by the issuer, verification from a reputable intermediary can nonetheless be valuable: the sponsor will be a known entity in the capital markets, and one who can assure investors as to the quality of the issuer's disclosures. ${ }^{39}$

\subsection{The Dominance of Disclosure}

Aside from such aspects, however, the dominant regulatory tool revolves around disclosure. Why might this be? First, quality screening and checks can only go so far in weeding out potential bad apples; indeed such requirements only focus on a limited amount of information about a company, especially when compared with the voluminous information required by the prospectus requirements. ${ }^{40} \mathrm{Next}$, and more pragmatically, disclosure is a

\footnotetext{
${ }^{35}$ See Consolidated Admissions Requirements Directive 2001/34/EC.

${ }^{36}$ See e.g. UK Listing Rule 6.2.1 (requiring applicants for a premium listing to have historical audited financials for the previous three years, which represents at least $75 \%$ of the applicant's business). Note that a similar requirement with respect to accounts (3 years or such shorter period as the applicant has been in operation) applies to applicants seeking a standard listing under the prospectus regime.

${ }^{37}$ See e.g. Commission Regulation (EC) No 809/2004, Annex I, paras 13 and 20.4.

${ }^{38}$ Gower: Principles of Modern Company Law (n 32) chapter 25.

${ }^{39}$ For further discussion on the limitations on such entities (and others) to act as effective intermediaries, see e.g. Jennifer Payne, 'The Role of Gatekeepers' in Niamh Moloney, Eilís Ferran and Jennifer Payne (eds), The Oxford Handbook of Financial Regulation (OUP 2015).

${ }^{40}$ Gullifer and Payne (n 17) chapter 10 . With respect to the level of detail in the current system, see Prospectus Directive Regulation, Annexes I-III.
} 
cheap tool for regulators; and it is likely to be favoured by market participants over more interventionist regulatory measures. ${ }^{41}$

So how can prospectus disclosure assist in weeding out the low-quality, and/or fraudulent issuers at the IPO stage, and thereby protect investors? ${ }^{42}$ First, shares are intangible goods; prospective investors cannot inspect them, or take them for a test drive as they might with a car: in economic parlance, the securities markets are a potential 'market for lemons'. ${ }^{43}$ Further, before the shares start trading, no market will exist for the shares, and no market price will have been established. Accordingly, it is tricky for prospective investors to value and price the shares that are on offer. Next, an asymmetry of information exists between the prospective external investors, and the company. Specifically, the firm and its insiders (especially the managers and directors) have an informational advantage over external investors; they know what a fair value is for their shares, and in the absence of information being disclosed, there is a risk that disreputable and fraudulent issuers try and sell overvalued shares to gullible investors. Further, in the absence of information, rational, informed investors will discount the price they are willing to offer to buy shares, as they will be unable to distinguish between the valuable securities, and the worthless ones. Consequently the fundamental principle of caveat emptor is modified to provide prospective rational investors with the information they need to make efficient resource allocation decisions: in the famous words of Justice Brandeis, 'sunlight is said to be the best of disinfectants'.$^{44}$ Finally, from the issuer's point of view, disclosure of information should reduce its cost of raising capital; rational investors will not discount the price they are willing to offer for their shares, as they will have received full information via which they can then value them.

Although this helps articulate the rationale for requiring disclosure at the IPO stage, a rich body of literature exists concerning the related issue as to whether or not issuers should be obliged to disclose information at the IPO stage (as well as subsequently once the shares are trading). ${ }^{45}$ For instance arguments can be advanced that high calibre issuers would always be incentivised to make full disclosure at the IPO stage even in the absence of mandatory requirements in order to distinguish themselves from less reputable firms. Further, sophisticated market participants can, and often do, bargain for what information is required in order to invest in a firm.

Nevertheless, on a traditional IPO, even if the lemons problem can ensure full disclosure by the good companies (enabling rational investors to also draw their own conclusions about other firms making insufficient disclosure), mandatory requirements still offer certain

\footnotetext{
${ }^{41}$ Luca Enriques and Sergio Gilotta, 'Disclosure and Financial Market Regulation' in Eilis Ferran, Niamh Moloney and Jennifer Payne (eds), The Oxford Handbook on Financial Regulation (OUP 2014).

${ }^{42}$ See also e.g. Reinier Kraakman and others (n 29), chapter 9 who use the terminology of affiliation strategies (as the authors state: 'the entry and exit of investors from the body of shareholders') and who articulate that the main method adopted by regulators relates to disclosure mechanisms.

${ }^{43}$ George Akerlof, 'The Market for "Lemons": Quality Uncertainty and the Market Mechanism' (1970) 84 Q J Econ 488.

${ }^{44}$ Louis D. Brandeis, Other People's Money and How the Bankers Use It (1914).

${ }^{45}$ See e.g. discussion in Donald C. Langevoort, 'Primary Markets and the Securities Laws: Capital Raising and Secondary Trading' (February 2017); Troy Paredes, 'Blinded by the Light: Information Overload and Its Consequences for Securities Regulation' (2003) 81 Washington University Law Review 417; Luca Enriques and Sergio Gilotta (n 41).
} 
advantages, not least ensuring the standardisation and uniformity of information, an outcome that should be of more aid to investors when comparing the different securities on offer ${ }^{46}$ Accordingly, the position today, in the EU, across the Atlantic, and further afield, is that mandatory disclosure is the norm. This is true, albeit that, particularly in the EU, the policy may stem as much from pragmatism rather than having a deeper philosophical origin. ${ }^{47}$

\section{EU Prospectus Regime: Reforms}

\subsection{Overview}

Applying this to the EU provisions, the disclosure requirements were first harmonised in the form of a directive in 2003. ${ }^{48}$ Broadly, the provisions laid down a single regime tackling the form, content, production, approval and publication of prospectuses throughout the EU. Common standards were introduced for prospectus disclosure, and issuers could passport prospectuses for cross border offers and listings following receipt of approval from the home competent authority. Overall, the regime was generally perceived to be functioning relatively well, but, particularly following the global financial crisis, when many smaller enterprises struggled to access traditional bank finance, the European Commission (the 'Commission') faced increasing calls to ease the burden on those seeking to tap external finance via the capital markets. Accordingly, prospectus proposals of a largely de-regulatory nature were introduced as part of the EU's wider Capital Markets Union programme (a project aimed more generally at strengthening the role of European capital markets, and reducing the over-reliance on bank lending), ${ }^{49}$ and this culminated in the adoption of the new regime.

With respect to the revamped rules, it should first be observed that, in connection with the broader post-financial crisis shifts in favour of greater convergence and the uniformity mode of harmonisation, the provisions take the form of a directly applicable regulation. ${ }^{50} \mathrm{Next}$, simple goals are articulated: the intention is to provide issuers with disclosure rules tailored

\footnotetext{
${ }^{46}$ John Coffee, 'Market Failure and the Economic Case for a Mandatory Disclosure System' (1984) 70 Va L Rev 717. Other arguments supporting mandatory disclosure include combatting well-known agency problems in companies. For instance managers may otherwise prefer not to disclose bad news, especially when their pay packets are tied to the performance of the company, see further e.g. Luca Enriques and Sergio Gilotta ( $\mathrm{n} 41$ ).

${ }^{47}$ See Niamh Moloney, EU Securities and Financial Markets Regulation (3rd edn, Oxford University Press, 2014) chapter II; see also Zohar Goshen and Gideon Parchomovsky, 'The Essential Role of Securities Regulation' (2006) 55 Duke LJ 711.

${ }^{48}$ Directive 2003/71/EC on the Prospectus to Be Published When Securities Are Offered to the Public or Admitted to Trading OJ L345/64. This was accompanied by a 'level 2 regulation, Commission Regulation $809 / 2004$. The regime has generally been considered to be a maximum harmonisation regime, see further Eilis Ferran and Look Chan Ho, Principles of Corporate Finance Law (2nd edn, OUP 2014), chapter 13; Pierre Schammo, EU Prospectus Law (CUP, 2011), chapter 3 (observing that paradoxically the directive does not explicitly identify the basis for the regime).

${ }^{49}$ See further, e.g. European Commission, Building a Capital Markets Union: Green Paper COM(2015) 63 Final (2015); European Commission, Review of the Prospectus Directive: Consultation.

${ }^{50}$ European Commission, Action Plan on Building a Capital Markets Union COM(2015) 468 Final. With respect to the wider post-crisis shift towards uniformity, see Niamh Moloney, 'EU Financial Market Regulation after the Global Financial Crisis: "More Europe" or More Risks?' (2010) 47 CML Rev 1317.
} 
to their needs, whilst also making the prospectus a more relevant tool for informing potential investors. ${ }^{51}$ Further, the reforms match parallel efforts taking place the US ${ }^{52}$ where a similar combination of seeking to ease access to finance for SMEs, plus a regulatory and political focus on promoting innovation to stimulate economic growth prompted reforms aimed at reducing or eliminating issuer disclosure requirements. ${ }^{53}$ Yet, although such policy visions may be undoubtedly well intended, they should also not risk 'losing sight' of the prospectus's investor protection function. ${ }^{54}$

With this in mind, this section examines the key themes deriving from two discrete aspects of the reforms; the summary, and the alleviated disclosure requirements introduced for small and medium sized enterprises ('SMEs'). ${ }^{55}$ Following the theoretical rationale for full and mandatory disclosure articulated in section 3, this part suggests that the ex ante provision of information in the prospectus can assist in furthering the policy aim of investor protection, but not necessarily in the way that is envisaged. Further, the focus of the reforms with respect to making disclosure easier for investors, including via shorter summaries, to understand is at odds with traditional arguments advocating detailed disclosure. More practically, it is also contrary with the reality, where any retail investors who do decide to purchase shares on an IPO are unlikely to rely on the documentation ex ante. ${ }^{56}$ Equally, although the drive to facilitate easier access for SMEs to market-based finance by policymakers is understandable, paring back the disclosure requirements may come into tension with the investor protection rationale.

\subsection{The Prospectus Summary}

It is often stated by policymakers that a prospectus is produced to provide investors with the information necessary to take an investment decision. ${ }^{57}$ Hence a vital tenet of a prospectus disclosure regime is that it is based on investors reading and processing the information provided. In this regard, and in line with the analysis in section 3, the prospectus is an extremely valuable source of information for informed market participants. Sophisticated

\footnotetext{
${ }^{51}$ European Commission, Proposal for a Regulation on the Prospectus to Be Published When Securities Are Offered to the Public or Admitted to Trading (COM(2015) 583 final).

52 European Commission, Proposal for a Regulation on the Prospectus to Be Published When Securities Are Offered to the Public or Admitted to Trading COM(2015) 583 Final (2015); Eilis Ferran and Look Chan Ho (n 48) chapter 13; Merritt Fox (n 3). On the US reforms, see also e.g. Securities Act Rule 506(c); Regulation A+.

${ }^{53}$ Merritt Fox (n 3); Eilis Ferran and Look Chan Ho (n 48) chapter 13. Note that with respect to the role short-term political factors can also play in driving such reforms forward, see e.g. John Coffee, 'The Political Economy of Dodd-Frank: Why Financial Reform Tends to Be Frustrated and Systemic Risk Perpetuated' (2012) 97 Cornell L Rev 1019.

${ }^{54}$ Niamh Moloney, 'Capital Markets Union: "Ever Closer Union" for the EU Financial System?' (2016) 41 European Law Review 307.

${ }^{55}$ Other aspects of the revisions focus on issuers already listed on a main securities market, and issuers of non-equity securities (such as bonds), see further e.g. Simon Bullock and others, Ashurts: New Prospectus Regulation: An Evolving Regime (June 2017).

${ }^{56}$ See Luca Enriques (n 11).

57 European Commission, Impact Assessment Accompanying Prospectus Regulation Proposal SWD(2015) 255 Final.
} 
prospective investors, market analysts, underwriters ${ }^{58}$ and other professional market players, will read and process the company's snapshot story, and institutional investors will use this information in deciding what is a fair value for the shares, and what they are willing to offer for the shares, ex ante. ${ }^{59}$

Nonetheless, and as is increasingly acknowledged by regulators, it is very unlikely that retail investors will read the full prospectus. ${ }^{60}$ When one reflects on the fact that the average length of a UK prospectus has increased over the decades from tens, to several hundred (or even a thousand) tightly condensed, often 'hard to understand' pages, these findings are not a surprise. ${ }^{61}$ With this in mind, it is particularly pertinent to hone in on the prospectus summary. Specifically, as this is likely to be the only part of the documentation retail investors consult (if they read any of the paperwork); policymakers have often wrestled with its precise format and content over the years. For instance, companies were initially granted considerable freedom over the summary, meaning issuers could, broadly, compose their own narrative, within some relatively informal limits as to length. This approach was widely perceived as a failure; the summary was often a 'copy-paste' operation from various other parts of the prospectus; the informal word limit risked constraining companies; and oversimplification had the potential to obscure the risks with the securities on offer. ${ }^{62}$ The summary was therefore overhauled as part of a wave of reforms in 2010, heralding in considerable changes to the summary's content, as well to its format.

In general terms, the amendments sought to harmonise the summary disclosures to try and make it easier for retail investors to compare different options. A prescriptive modular format was also introduced, with a length limit specified of seven per cent or 15 pages, whichever was shorter. Perhaps predictably, however, this resulted in the production of highly prescriptive mini-prospectuses that were considered unwieldy and unreadable. ${ }^{63}$ Previous problems persisted; the summary remained a cut and paste exercise without any

\footnotetext{
${ }^{58}$ In general terms, the investment bank (or banks) that underwrites the flotation provide a type of insurance policy for the company in the event the shares are not taken up, whereby the bank, may, for example agree to subscribe for shares not purchased.

${ }^{59}$ This will be used in conjunction with the wider investor education process that takes place during the run-up to the flotation. Note as well that in this regard, due to perceived deficiencies in the availability of information during the IPO process, the UK regulator is currently publishing new provisions intended to improve the range, quality and timeliness of information available to market participants on an IPO, see further Financial Conduct Authority, Reforming the Availability of the Information in the UK Equity IPO Process Policy Statement Ps17/23 (October 2017).
}

${ }^{60}$ Niamh Moloney, How to Protect Investors (CUP 2010) chapter 5; Centre for Strategy and Evaluation Services, Study on the Impact of the Prospectus Regime on EU Financial Markets (June 2008). Notably, as well, this CSES study also found that such investors will instead be more likely to rely on the prospectus ex post. See also European Commission, Impact Assessment Accompanying Prospectus Regulation Proposal SWD(2015) 255 Final.

${ }^{61}$ TNS-Sofres, Report for AMF: Investigation of Investment Information and Management Processes and Analysis of Disclosure Documents for Retail Investors (2006); European Commission, Impact Assessment Accompanying Prospectus Regulation Proposal SWD(2015) 255 Final.

62 European Commission, Impact Assessment Accompanying the Proposal Amending the Prospectus Directive SEC(2009) 1223 (2009); Moloney, EU Securities and Financial Markets Regulation chapter II.

63 European Commission, Impact Assessment Accompanying Prospectus Regulation Proposal $\operatorname{SWD}(2015) 255$ Final. 
effort to simplify legal terminology or to frame it in a way that was easy to understand by a consumer. The end result was that retail investors refrained from reading it. ${ }^{64}$

The current reincarnation of the rules continues to grapple with these issues and demonstrates that the pendulum is now swinging back, to an extent, towards the original approach. In particular, issuers are granted more discretion to select the information they deem material and meaningful. Further, in an effort to tackle perceptions of inaccessibility, the summary is required to be written in plain, non-technical language, and be 'short, simple and easy for investors to understand' ${ }^{65}$ Despite this, a number of prescriptive elements remain in terms of both form and indicative content, and summaries are now closely modelled on the supposedly consumer-friendly key information documents ('KIDs') that are required for packaged retail and insurance-based investment products. Linked to this, the length limit for summaries is now reduced to seven pages, with a further, rather arbitrary, provision requiring that only the 15 most material risk factors be included (although this is likely in an attempt to tackle the concerns as to information overload).

The continued regulatory focus on the prospectus summary is understandable to an extent; it is not easy to put together an 'optimal' regulatory system for the protection of retail investors. ${ }^{66}$ It is also commendable that policymakers have tried to respond to the failures of the summary 'model II' and to address the challenges in a more nuanced fashion. Yet, pitfalls abound. Despite the summary being mirrored on the KIDs, the question as to the precise format of the KIDs was tested on consumers with a view to ensuring they could be as helpful and meaningful to consumers as possible: ${ }^{67}$ the same has not occurred with the prospectus summary. On the other hand, perhaps this is just as well: the KIDs survey reiterated that even when information was presented to consumers using simple wording and format, a large group of retail investors remained unable to draw the correct conclusions, and there remained a number of specific areas of continued confusion. ${ }^{68}$ Indeed such findings are also emphasised by the cognate behavioural finance scholarship that demonstrates that at some point 'information overload' will lead to consumers making worse decisions than if less information were available. ${ }^{69}$ Equally, if processing the information is more costly than the expected benefits, ignoring the information may be the more efficient decision: rational ignorance. ${ }^{70}$

\footnotetext{
64 Ibid.

65 Prospectus Regulation, recitals 30 and 31; article 7. See also the functional equivalent in the US where the 'Plain English' disclosure rule applies with respect to certain aspects of the prospectus including the summary.

${ }^{66}$ Eilis Ferran, 'Cross-Border Offers of Securities in the EU: The Standard Life Flotation' (n 22).

${ }^{67}$ London Economics and Ipsos, Consumer Testing Study of the Possible New Format and Content for Retail Disclosures of Packaged Retail and Insurance Based Investment Products (Final Report MARKT/2014/060/G, 2014).

${ }^{68}$ Ibid; Veerle Colaert, 'The Regulation of PRIIPs: Great Ambitions, Insurmountable Challenges?' (January 2016).

${ }^{69}$ Paredes (n 45); Omri Ben-Shahar and Carl E. Schneider, 'The Failure of Mandated Disclosure' (2011) 159 University of Pennsylvania Law Review 647 (involving a comprehensive review of the use and failure of mandatory disclosure in a wide range of scenarios from patient informed consent to contract formation).

${ }^{70}$ Colaert; Robert Prentice, 'Whither Securities Regulation? Some Behavioral Observations Regarding Proposals for Its Future' (2002) 51 Duke ᄂ 1397; Niamh Moloney (n 60) chapter 5.
} 
Taken together, what becomes clear is that the disclosure of information does not directly protect retail investors ex ante. ${ }^{71}$ Even if consumers read the summary, or the full prospectus, they are not necessarily able to draw the correct conclusions from the information provided, and they may make irrational choices, regardless. Accordingly a clear disconnect exists between the reality where retail investors do not read the paperwork, and the approach taken by regulators in seeking to ensure that prospectus disclosures are easily accessible to them. ${ }^{72}$ Indeed, when one also keeps in mind that retail investors are only involved directly with the EU's capital markets today to a relatively limited extent, ${ }^{73}$ one may start to question the continual energy being poured into the precise form and content of the summary by regulators every few years. ${ }^{74}$

On a more auspicious note, however, unsophisticated retail investors remain protected by prospectus disclosure indirectly. First, all related marketing material produced in line with the flotation, which the retail public may read, is required to properly reflect what is written in the prospectus, thereby providing a type of indirect legal protection. Next, retail investors can 'piggyback' off the efforts of sophisticated institutional investors and others at the IPO stage that do use the prospectus disclosures in order to make an informed assessment. ${ }^{75}$ Finally, the prospectus may also offer greater legal protection to retail investors ex post in the event of inaccuracies, ${ }^{76}$ although this will also be dependent on the related factors articulated in section 2, including the particular Member State's legal regime, which will decree who can bring a claim, as well as related procedural factors including ease of access to the courts.

\subsection{Modifications for Small and Medium-Sized Enterprises}

A further aspect of the prospectus regime that came in for criticism in advance of the current wave of reforms was the proportionate disclosure regime introduced for SMEs in $2010 .^{77}$ Prior to this, the prospectus disclosure rules (to a large extent) operated on a one size fits all basis. ${ }^{78}$ Factoring in the cost implications of preparing a prospectus (estimates

\footnotetext{
${ }^{71}$ See e.g. Frank H. Easterbrook and Daniel R. Fischel, 'Mandatory Disclosure and the Protection of Investors' (1984) 70 Va L Rev 669 who state that the arguments in favour of retail investor protection are 'as unsophisticated as the investors it is supposed to protect'.

72 John Armour and others, Principles of Financial Regulation (OUP 2016), chapter 8.

${ }^{73}$ E.g. the Commission has highlighted that direct share ownership of European households has fallen from 28\% in 1975 to $10-11 \%$ since 2007, European Commission, Action Plan on Building a Capital Markets Union COM(2015) 468 Final.
}

${ }^{74}$ Note as well that companies may also have legitimate concerns with respect to potential liability risks created by the new summary when it is required to be accurate, fair, not misleading as well as being concise. See Prospectus Regulation, article 7(5), Simon Bullock and others, New Prospectus Regulation: An Evolving Regime (2017).

${ }^{75}$ Armour and others chapter 8 (n 72); Luca Enriques (n 11).

${ }^{76}$ Centre for Strategy and Evaluation Services (n 60); European Commission, Impact Assessment Accompanying Prospectus Regulation Proposal SWD(2015) 255 Final.

${ }^{77}$ SMEs can be the subject of a number of different definitions; the main factors are the company's employee headcount, and either its turnover or balance sheet total, see Prospectus Regulation, art 2(f).

${ }^{78}$ Although the provisions have always exempted small offers, and the new rules will not apply to offers of securities to the public with a total consideration of less than $€ 1$ million, ibid article 1(3). 
vary but for a share issue prospectus, costs can range from an average of almost $€ 700000$ to $€ 1.3$ million), ${ }^{79}$ there was little incentive for small firms to incur such costs, particularly given the relatively small amount of capital they (generally) sought to raise. Rather, smaller firms relied heavily on bank finance or, more recently, increased their recourse to innovative forms of financing. ${ }^{80}$

The difficulties SMEs faced when accessing market-based finance had been on regulators' radar for some time, and the previous prospectus amendments introduced an alleviated disclosure regime for SMEs. ${ }^{81}$ Yet the modified route was hardly ever used; for instance in 2014 , only 94 out of a total of 3838 prospectuses were drawn up using the modified regime. ${ }^{82}$ This was partly due to the fact that the reforms introduced very little alleviation from the full-blown disclosure requirements; further, the firms that could have made use of the provisions tended not to, due to the disadvantage of being perceived by prospective investors as providing limited information, plus the related greater liability risk in the absence of full disclosure. ${ }^{83}$

As already identified, the policy focus on SMEs was then sharpened by the global financial crisis ${ }^{84}$ Bank financing became extremely hard to obtain, and SMEs (generally regarded as having a higher probability of default) were penalised. ${ }^{85}$ Accordingly, facilitating easier access to the capital markets, whilst seeking to rectify the failings of the prior reforms, became a policy priority. Yet, although the continued regulatory efforts to facilitate easier access to the capital markets for smaller firms can be acknowledged as a laudable policy attempt to reduce reliance on bank-based financing, this stance can also come into tension with the wider aim of investor protection. ${ }^{86}$ Most pertinently, the question as to whether mandatory disclosure requirements should be reduced for SMEs is a tricky one. It is clear that, on the one hand, the costs of preparing a full prospectus, plus the related costs associated with coming to market, can be exorbitant; but on the other, the concerns as to SMEs' risk profile are not unwarranted. Fledgling SMEs with untested business ideas or products are, by their nature, likely to be a higher risk investment than investing in a wellestablished firm, and, if anything, investors may in fact require greater, rather than

79 European Commission, Impact Assessment Accompanying Prospectus Regulation Proposal SWD(2015) 255 Final. This included fees involved pertaining to auditors and accountants, legal and financial advisers, regulatory fees etc., all of which will vary on a case-by-case basis.

${ }^{80}$ See e.g. John Armour and Luca Enriques, 'The Promise and Perils of Crowdfunding' (Working Paper, October 2016).

${ }^{81}$ See further, e.g. European Commission, Impact Assessment Accompanying the Proposal Amending the Prospectus Directive SEC(2009) 1223.

82 European Commission, Impact Assessment Accompanying Prospectus Regulation Proposal SWD(2015) 255 Final.

83 Ibid.

${ }^{84}$ Moloney, EU Securities and Financial Markets Regulation (n 47) chapter II.

${ }^{85}$ European Commission, Initial Reflections on the Obstacles to the Development of Deep and Integrated EU Capital Markets: Working Document Accompanying the Green Paper SWD(2015) 13 Final (2015); see further also e.g. Elif Härkönen, 'Crowdfunding and the Small Offering Exemption in European and US Prospectus Regulation: Striking a Balance between Investor Protection and Access to Capital?' (2017) 14 ECFR 121.

${ }^{86}$ See e.g. ESMA, Technical Advice on Possible Delegated Acts Concerning the Prospectus Directive as Amended by the Directive 2010/73/EU (ESMA/2011/323) section VIII (particularly advocating caution in this area due to the risks to investor protection). 
alleviated, standards of disclosure for SMEs, before being prepared to purchase their shares. ${ }^{87}$

With respect to the new rules, however, the capital formation rationale presides. The series of reforms include, for example, an exemption raising the bar of an offer size under which a prospectus is not required (previously €5 million consideration, now €8 million), ${ }^{88}$ and also introduce an optional and lighter harmonised disclosure regime for SMEs: termed an EU growth prospectus regime. This option is available to smaller issuers on an offer of shares to the public, although not where such issuers will have their shares admitted to trading on a regulated market (such as the London Stock Exchange's Main Market). ${ }^{89}$ This restriction aims to avoid a type of two-tier disclosure; investors on a regulated market should be confident they are reviewing the sole set of disclosures without the concern that a more comprehensive set of disclosures could exist elsewhere. ${ }^{90}$ Although the devil will be in the detail of the subsequent delegated rules, this abbreviated prospectus is to have a standardised format and sequence, be written in simple language, and be easy for issuers to complete. It will also be eligible, once approved, to be passported elsewhere in the EU. ${ }^{91}$

It remains to be seen what use is made of the new option; certainly, a SME considering a public offer may be more likely to tap a smaller trading venue (such as the London Stock Exchange's junior market, AIM, rather than its regulated big brother, the Main Market), and investors using such second tier venues are thought to better understand the risks they run. ${ }^{92}$ Yet, given that the admissions process and the efforts of institutional investors already act as a type of proxy for investor protection with respect to such markets, the reforms may suggest, as Moloney articulates, a 'misunderstanding of the dynamics' of such trading venues. ${ }^{93} \mathrm{Next}$, as an EU growth prospectus will be different to a regulated market prospectus, this could also risk resulting in investor confusion. ${ }^{94}$ Further, given that issuers will remain subject to the risk of litigation in different jurisdictions, and as the precise liability regime varies country to country, this could lead to a limited uptake of the passport option. Indeed, given the local roots of many small companies, such firms may be more likely to rely on local investors rather than seeking to raise finance further afield. Similarly, in line with the rigmarole surrounding the prospectus summary, and the previous set of proportionate disclosure rules, introducing a new set of prescribed provisions for SMEs may not be as 'SME friendly' as currently envisaged. Finally, as a more general point of principle, if SMEs are a higher risk investment, and if a prospectus should be primarily an investor

\footnotetext{
${ }^{87}$ Armour and others (n 72) chapter 8.

${ }^{88}$ Prospectus Regulation, article 3(2) (note this is only optional so a Member State could in principle choose a lower threshold provided it did not go below the $€ 1$ million threshold below which no prospectus is required, see article 1(3)).

${ }^{89}$ Ibid, recital 53; art 15. Note that article 15 also embraces certain issuers other than SMEs (e.g. if the public offer does not exceed a certain cap and subject to an employee headcount).

${ }^{90}$ European Commission, Proposal for a Regulation on the Prospectus to Be Published When Securities Are Offered to the Public or Admitted to Trading; Norton Rose Fulbright, Prospectus Regulation Proposal (2017).

${ }^{91}$ Prospectus Regulation, recital 51; art 15(1).

${ }^{92}$ Gower: Principles of Modern Company Law (Paul L. Davies and Sarah Worthington eds, 10th edn, Sweet \& Maxwell 2016) chapter 25.

${ }^{93}$ Moloney, 'Capital Markets Union: "Ever Closer Union" for the EU Financial System?' (n 54).

94 Ibid.
} 
protection device, then one should be hesitant before alleviating rules; rather, it may be more realistic to recognise that a public offering is simply an impractical source of funds for some types of smaller company. ${ }^{95}$

\section{Policy Choices: Which Way Now for the UK?}

The preceding sections' analysis illustrates, first, that there is a strong theoretical, albeit also pragmatic, foundation behind imposing full and mandatory disclosure on issuers seeking to tap the public markets; and further that aspects of the new EU provisions may be at odds with the policy goals on which a strong prospectus regime should be premised. This section now draws on this analysis to look to the future, in the light of Brexit. The UK's decision to leave the EU will lead to profound legal, political, and economic consequences, the full ramifications of which are hard to predict with any degree of certainty. At the time of writing, the terms of any final Brexit deal remain a long way off, and a broad range of possible outcomes can be envisaged, with varying degrees of impact on the EU and UK's capital markets. ${ }^{96}$ Yet taking a sanguine view, there can be opportunities amidst the turmoil. Arguably, this is all the more true when one bears in mind the UK's prominent position as a global financial centre, ${ }^{97}$ and as the jurisdiction with the most developed EU capital marketbased system. ${ }^{98}$ With this in mind, this section considers possible policy routes for the UK's future prospectus regime, using the EU position as the starting point, and premised on the assumption that the UK will leave the single market when it departs from the EU. It examines three options and it speculates that the third, of creating a super-equivalent framework, is the most preferable.

\subsection{Option One: Retain the Status Quo}

The simplest option, and in some ways, the most likely, is to maintain the current state of affairs: to continue complying with the EU regime. Indeed, the European Union (Withdrawal) Bill purports to convert EU law into domestic law as it stands at the moment of the UK's withdrawal, currently scheduled for 29 March 2019 (although there is now the ability for this to be extended if the EU agrees). ${ }^{99}$ Accordingly, EU law should simply continue to apply in the UK following Brexit as it did before. At first glance, with respect to securities law, this suggests that the EU prospectus regime will continue to operate as it did before. In this regard it should be kept in mind that although the recent prospectus reforms took effect in all Member States from July 2017, the bulk of the changes do not directly apply until 21 July

\footnotetext{
${ }^{95}$ Merritt Fox (n 3).

${ }^{96}$ See Oliver Wyman (n 5); John Armour (n 7).

${ }^{97}$ The financial services industry constitutes approximately 7\% of UK GDP; employs over one million people (two-thirds outside London) and contributes a significant proportion of tax revenue, House of Lords European Union Committee, Brexit: Financial Services (2016); John Armour (n 7).

${ }^{98}$ Wolf-Georg Ringe, 'The Irrelevance of Brexit for the European Financial Market' (Oxford Legal Research Paper: January 2017).

${ }^{99}$ European Union (Withdrawal) Bill 2017, clause 2; clauses 14(2) and (4). Moreover, cf. Article 122 of the European Commission Draft Withdrawal Agreement on the withdrawal of the United Kingdom of Great Britain and Northern Ireland from the European Union and the European Atomic Energy Community, which says that Union law shall be applicable to and in the United Kingdom during the transitional period which ends on 31 December 2020 (according to Article 121).
} 
2019 (largely to facilitate the production of intricate delegated rules that will flesh out the bones of the rules, including the changes considered in section 4). Taken together, this suggests that the existing prospectus rules will continue to apply until 20 July 2019, and that the new provisions will then take effect the following day.

Yet, this may not be so straightforward in practice. In relation to the conversion of EU law into domestic law, the drafting of the EU Withdrawal Bill excludes EU legislation that is in force but does not apply or take effect before exit day. ${ }^{100}$ Accordingly, as the majority of the new rules do not directly apply until July 2019, this suggests that the new EU prospectus regime could cease to operate in the UK following Brexit day. ${ }^{101}$ Further, although the Bill confers rather extensive powers on government ministers to make regulations, including in order to remedy any failure of retained EU law to operate effectively, it is debatable whether such powers could extend this far. ${ }^{102}$ With this in mind, a somewhat peculiar end result could be that of parallel regimes operating from 21 July 2019, with the majority of the old EU regime continuing to operate in the UK, whilst the new rules kick in elsewhere.

Whether or not this is ironed out (and it is probable that such issues will arise elsewhere), there is a further important question raised by seeking to retain the status quo: equivalence. Specifically, based on the assumption that the UK is leaving the single market (often referred to as a 'hard' rather than a 'soft' Brexit), and even if the UK does choose to adopt the EU's prospectus regime, in principle, as a third country, it will no longer be eligible to simply passport an approved prospectus elsewhere in the EU. Indeed, depending on the precise terms of the UK's exit, it may be that the UK has to instead rely on the EU's complex third country equivalence regime; an issue that has become particularly topical throughout EU financial services regulation more broadly in the light of Brexit. ${ }^{103}$ In practical terms, the UK only in fact passported a slim percentage (under five per cent) of its prospectuses into other EU jurisdictions in 2016, ${ }^{104}$ which perhaps suggests that this issue might only arise in a slim minority of cases, nonetheless, its importance should not be underestimated. Specifically, having the opportunity to market a public offer elsewhere in the EU can be very appealing for a firm, particularly on a large IPO involving a retail element. ${ }^{105}$ This option also increases the available capital pool for a company, and it enhances the possible investment

\footnotetext{
100 Ibid clauses 2 and 3(3)(a).

${ }^{101}$ Ashurst, Which Prospectus Regime Will the UK Have after Brexit? (July 2017). Note that this would be aside from a minority of changes that took effect in advance of July 2019.

${ }^{102}$ This is all the more true given the Bill expressly provides that EU law is not deficient merely because it does not contain any modification that only (amongst other situations) applies on or after exit day, see European Union (Withdrawal) Bill 2017, clause 7(3); Ashurst (n 101). Note that such ministerial powers are now to be also overseen by a scrutiny committee, see European Union (Withdrawal) Bill 2017, Schedule 7, part 1, section 3; Heather Stewart, 'Theresa May Forced to Accept New Brexit Scrutiny Committee' The Guardian (11 December 2017) <https://www.theguardian.com/politics/2017/dec/11/theresa-may-forced-accept-brexit-scrutinycommittee-revolt-henry-viii-powers> accessed 3 January 2018.
}

${ }^{103}$ See e.g. Eilis Ferran, 'The UK as a Third Country Actor in EU Financial Services Regulation' (n 12); Niamh Moloney, 'Negotiating a Financial Services Deal' (LSE Brexit Special 6: Policy Briefing 25 (2017)).

${ }^{104}$ ESMA, EEA Prospectus Activity in 2016 (n 1), figures calculated according to ESMA's report where 27 out of a total of 838 prospectuses were passported out of the UK in 2016.

105 Charles Howarth, Why Brexit Will Be No Problem for London's IPO Market in the Long Term (2016). 
opportunities for investors. ${ }^{106}$ Moreover, the alternative, of a firm having to rely on a cumbersome third country equivalence regime, will add to the time and expense of a public offer, without any guarantee that a prospectus will then be approved.

Focusing on the nuts and bolts of the prospectus equivalence regime, it should first be observed that although the term 'equivalence' can be hard to define, the general idea is clear; two sets of rules that are sufficiently similar or functionally substitutable. ${ }^{107}$ In this regard, the new EU prospectus regulation requires issuers from outwith the EU (third country issuers) to either prepare a prospectus in accordance with the Prospectus Regulation and obtain the approval of the local regulator; or to draw up a prospectus in accordance with national legislation, which is deemed to be equivalent by the Commission. ${ }^{108}$ In the event an equivalence decision is made, however, this is not binding on the local regulator, which still has the ultimate discretion as to whether or not to approve the prospectus. ${ }^{109} \mathrm{Next}$, the new EU rules also bolt on an extra condition: the conclusion of a cooperation arrangement between the third country's supervisory authority, and that of the Member State in question. ${ }^{110}$ As the cooperation requirements were added on following the Brexit vote, it has been queried whether the referendum result contributed to their inclusion, ${ }^{111}$ but it should also be recognised that such arrangements have become a standard aspect of the single EU financial rulebook that materialised following the financial crisis, in line with wider, international aspirations towards international cooperation and regulatory and supervisory convergence. ${ }^{112}$

With this in mind, on the one hand, this set up could offer a relatively flexible system, provided the necessary agreements are concluded. Nonetheless there are further issues to bear in mind. The existing third country equivalence regime has been rarely used with

\footnotetext{
${ }^{106}$ Andreas Kokkinis, 'The Impact of Brexit on the Legal Framework for Cross-Border Corporate Activity' (2016) 27 European Business Law Review 959.

107 Tzung-bor Wei, 'The Equivalence Approach to Securities Regulation' (2007) 27 Nw J Int'I L \& Bus 255.

108 Prospectus Regulation, articles 28 and 29.

109 Once the prospectus is approved, however, the regulator passporting provisions will then apply, see ibid, article 29(2) in conjunction with articles 24, 25 and 27.
}

${ }^{110}$ See Council of the European Union, Confirmation of the Final Compromise Text (ECOFIN 1187) (December 2016) art 27; Prospectus Regulation art 29.

${ }^{111}$ See Norton Rose Fulbright, Non--EU Prospectus Equivalence (2017).

112 Note as well that, unlike some recent EU measures, no reciprocity requirements appear to apply under the current EU third country prospectus provisions. Such requirements would mean that the third country (i.e. the UK) framework must also provide for reciprocal arrangements for EU companies wanting to offer shares to investors in the UK. That said, the UK regulator will still be able to concur that an approved EU prospectus suffices where an EU firm wishes to offer shares in the UK, and there would certainly be a rationale for it doing so, see further John Armour (n 7); Norton Rose Fulbright, Impact of Brexit on Corporates (July 2016). At the same time, however, also note recent Commission proposals which suggest that the Commission could bolt on additional conditions to prospectus equivalence decisions, including a requirement that a third country provides an equivalent regime for recognising a prospectus drawn up in accordance with the EU prospectus regime, see European Commission, Reinforcing Integrated Supervision to Strengthen Capital Markets Union and Financial Integration in a Changing Environment COM(2017) 542 Final (September 2017). 
respect to prospectuses, ${ }^{113}$ and the Commission has not embraced its power under the existing system to establish general equivalence criteria. ESMA has established a framework for assessing third country prospectuses, ${ }^{114}$ but to date it has issued only two equivalence opinions, the first, that a prospectus drawn up in accordance with Turkish law would be deemed equivalent; the other on the extra information that would need to be included in a 'wrap' to a prospectus drawn up according to Israeli law to make it equivalent. ${ }^{115}$ Although the equivalence regime's infrequent use is not necessarily problematic, there is the related legitimate concern that equivalence decisions under the new prospectus regime could become a lengthy and a politicised process. ${ }^{116}$ On the pragmatic point as to timing, there is certainly, currently, 'no right' to be judged equivalent, meaning the UK could be, in essence, at the mercy of the Commission. ${ }^{117}$

Turning to the risk of political influence, on the one hand, it could be that some of the fears as to political influence are unfounded; especially factoring in the important role of ESMA, a technocrat, who will have considerable input in providing detailed technical advice to the Commission on equivalence criteria, and with respect to the minimum content of the cooperation arrangements. ${ }^{118}$ Yet on the other hand, one should also bear in mind that under the current equivalence framework for assessing third country prospectuses, ESMA has taken a literal approach to assessing similarities and differences. ${ }^{119}$ Accordingly, it may be the case that ESMA adopts a similar stance going forward. ${ }^{120}$ Finally, even if the UK's prospectus legislation is initially deemed (as would seem likely) to be equivalent at the point of exit, in the event that the UK legislation started to diverge from the EU's, there remains the risk that the equivalence decision could be subsequently withdrawn, with little or no right of appeal.

\subsection{Option Two: 'Singapore-on-Thames'?}

\footnotetext{
${ }^{113}$ See Prospectus Directive, art 20 (in general terms, requiring a prospectus be drawn up in accordance with international standards, and for the information requirements to be equivalent to the EU provisions).

${ }^{114}$ ESMA, Framework for the Assessment of Third Country Prospectuses under Article 20 of the Prospectus Directive.

${ }^{115}$ ESMA, Assessment of Turkish Laws and Regulations on Prospectuses (ESMA/2016/268); ESMA, Assessment of Israeli Laws and Regulations on Prospectuses (ESMA/2015/1015); Norton Rose Fulbright, Market Access after Brexit: Prospectus Equivalence (2017).

${ }^{116}$ House of Lords European Union Committee (n 97).

117 Ibid.

${ }^{118}$ Niamh Moloney, 'Financial Services, the EU, and Brexit: An Uncertain Future for the City?' (2016) 17 German $U$ 75; John Armour (n 7). See also Niamh Moloney, 'International Financial Governance, the EU, and Brexit: The 'Agencification' of EU Financial Governance and the Implications' (2016) 17 EBOR 451.

${ }^{119}$ ESMA, Framework for the Assessment of Third Country Prospectuses under Article 20 of the Prospectus Directive; Eilis Ferran and Look Chan Ho (n 48) chapter 14.

${ }^{120}$ Note that recent Commission proposals also advocate third country issuers filing a prospectus with ESMA. ESMA will take over the role of the home competent authority with respect to approval, meaning all prospectuses issued by UK entities and offered to the public in the EU will be subject to ESMA's approval, see European Commission, Reinforcing Integrated Supervision to Strengthen Capital Markets Union and Financial Integration in a Changing Environment COM(2017) 542 Final.
} 
Given the vagaries and complexities associated with equivalence, a more radical alternative can be contemplated. This could involve the UK abandoning the red tape of EU legislation and looking to pare back the existing prospectus regime, as well as the associated legal and administrative burden that comes with a stock market listing. Such a model would be especially geared towards guaranteeing London's position as a popular destination for issuers seeking access to its capital markets. Certainly, from a political perspective, such a proposal would likely be welcomed by staunch Brexiteers who tend to espouse strong rhetoric in the media about the merits of softer regulation, and of turning Britain into a lightly regulated, low-tax, jurisdiction: sometimes referred to as a Singapore-on-Thames' regime. ${ }^{121}$ Indeed, such arguments are often framed along the lines of making the City as attractive to businesses as possible, as well as posing a competitive threat to the remainder of the EU; a type of 'regulatory competition' model. Yet, this over-simplifies the story.

Focusing specifically on the prospectus and listing regimes, this paper has speculated that some of the more de-regulatory aspects of the recent EU prospectus reforms may be found wanting; and that the importance of providing full and accurate information to prospective rational investors ex ante to tackle the asymmetries of information that exist between issuers and investors at the IPO stage should not be underestimated. Equally, although the UK regulator is currently consulting on creating a new category of premium listings for stateowned companies that would pare back particular requirements for such organisations, ${ }^{122}$ these proposals have met with considerable opprobrium from (amongst others) institutional investors and asset managers. Such market participants fear that relaxing the rules in order to accommodate such companies could come at the expense of investor protection, and could damage the reputation of London's premium listing segment. ${ }^{123}$ Such criticisms are well founded; investors consider London as a highly attractive market partly due to the development of the 'brand' associated with its high calibre listing requirements and robust legal architecture. ${ }^{124}$ Indeed, in relation to the UK regulator's current attempt to woo Saudi Aramco, it could also be the case that the 'victor' of this particular competition is not even the UK, but rather New York. ${ }^{125}$

Moreover, with respect to financial and capital markets regulation more generally, a lively debate exists in the legal scholarship with respect to the benefits of regulatory

\footnotetext{
${ }^{121}$ See further e.g. City Political Economy Research Centre, A Singapore on the Thames: Policy Report (May 2017); Rowena Mason, 'Tory MPs Suggest Firms Draw up List for Bonfire of EU Laws after Brexit' The Guardian (7 December 2016).

${ }^{122}$ Financial Conduct Authority, Proposal to Create a New Premium Listing Category for Sovereign Controlled Companies: Consultation Paper 17/21. In general terms, these amendments would mean that protections that are in place for minority shareholders where there is a controlling shareholder would not apply; and that a sovereign controlling shareholder would not be considered a related party, meaning prior scrutiny and independent shareholder approval would not be required before a transaction or arrangement was entered into between the listed company and the related party.

123 'London Reforms Set to Open Door for Saudi Aramco Listing' The Financial Times (13 July 2017). In this regard, history could also repeat itself; the UK regulator has previously had to tighten up the listing requirements on foreign owned companies seeking premium London listings after stock market scandals involving resource companies (ENRC and Bumi) from emerging markets, see David Oakley, 'Market Gatekeeper to Tighten London Listing Rules' The Financial Times (5 November 2013); Eilis Ferran, 'Corporate Mobility and Company Law' (2016) 79 Modern Law Review 813.

${ }^{124}$ Financial Conduct Authority, Review of the Effectiveness of Primary Markets: The UK Primary Markets Landscape: Discussion Paper 17/2 (2017) chapter 2.

${ }^{125}$ Wolf-Georg Ringe (n 20).
} 
competition, ${ }^{126}$ including that it can facilitate the tailoring of laws to a jurisdiction's specific circumstances, and that it can encourage innovation in order to attract businesses and market players. Equally, market participants can benefit from taking advantage of such competition by engaging in regulatory arbitrage; firms can relocate to a jurisdiction that is more efficient and less costly than their domestic regime. ${ }^{127}$ Yet, there are also drawbacks. For instance (and on an issue that extends beyond the prospectus system) in an attempt to compete for business following Brexit, the UK could aggressively de-regulate, whilst multiple EU jurisdictions also compete with one another, and with the UK, in order to entice businesses based on the promise of unhindered access to the internal market (a state of affairs which may be already materialising). ${ }^{128}$ This could all culminate in a downward spiral in regulatory and supervisory standards, a situation that, at least in theory, could risk threatening the stability of the markets. ${ }^{129}$ This is, presumably, not a scenario that any politician or policymaker would ever wish to encourage, not least as the last financial crisis remains fresh in the minds of many investors.

Accordingly, with respect to the future of the UK's prospectus legislation, it is suggested that any proposed regulatory shifts that are geared towards simply breaking free of the red tape of EU rules should be resisted. Embarking on such a path could risk jeopardising London's appeal and international standing as a listing venue: a reputation rooted in the UK's robust legal framework, which investors trust, and which other jurisdictions currently look to as an example. ${ }^{130}$

\subsection{Option Three: The 'Gold' Route}

With this in mind, the third alternative involves the UK choosing to fashion its own regulatory route over the longer term. Rather than a simple retention of the status quo, or the alternative of tearing up the current rules, this course of action would entail the UK adopting the EU prospectus regime as its starting point, but would then offer the regulator more flexibility over the longer term to experiment to some extent, and to bolster this framework using gold plated rules. Indeed, such a notion has been canvassed by the governor of the Bank of England with respect to other aspects of financial regulation surrounding Brexit, ${ }^{131}$ where it has been suggested that this could ensure, for instance, that

\footnotetext{
${ }^{126}$ See e.g. Simon Deakin, 'Legal Diversity and Regulatory Competition: Which Model for Europe?' (Centre for Business Research, University Of Cambridge Working Paper No 32, 2006). Particularly with respect to the US, see e.g. Roberta Romano, 'The Need for Competition in International Securities Regulation Protecting Investors in a Global Economy' (2001) 2 Theoretical Inquiries in Law 387; cf Merritt B. Fox, 'The Issuer Choice Debate Protecting Investors in a Global Economy' (2001) 2 Theoretical Inquiries in Law 563.
}

127 See further e.g. Moloney, EU Securities and Financial Markets Regulation (n 47), chapter I.

${ }^{128}$ See e.g. 'Frankfurt Takes Early Lead in Brexit Race to Poach City Jobs' The Financial Times (21 March 2017).

${ }^{129}$ Wolf-Georg Ringe (n 20). See further also, John Coffee, 'Law and Regulatory Competition: Can They Co-Exist Symposium: What We Know and Do Not Know About the Impact of Civil Justice on the American Economy and Polity: Commentary' (2001) 80 Tex L Rev 1729.

${ }^{130}$ Financial Conduct Authority, Review of the Effectiveness of Primary Markets: The UK Primary Markets Landscape: Discussion Paper 17/2, chapter 2.

${ }^{131}$ See e.g. Ben Wright, "Super Equivalence' Needs New International Regulator, Says City' The Telegraph (4 March 2017) (looked at from the perspective of institutions and/or countries meeting international financial standards to ensure they can retain cross-border access to European markets). 
financial institutions could continue to have stable cross-border access to the EU markets following Brexit.

Focusing on the prospectus rules, an equivalence-plus model would seek to endorse and then expand upon what is laid down, both in high-level international law standards of securities regulation (a previous incarnation of which formed the basis of the EU's initial prospectus regime), as well as what is prescribed by EU legislation. ${ }^{132}$ This super-equivalent approach could also be in line with influential academic scholarship that has demonstrated (in the context of issuers cross-listing on foreign exchanges) that issuers can be attracted to regulatory regimes that have strong legal standards; namely higher disclosure standards or where there is a greater threat of enforcement. In this regard, a firm 'bonding its promise' to a strong legal system can signal its quality, and can reduce the information asymmetries between itself and its outside investors, which may lower its cost of capital. ${ }^{133}$ Moreover, although it is acknowledged that in today's world, much international capital markets activity tends to be structured so as to fall within exemptions to prospectus regimes, bonding may continue to play an important role, not least because there continue to be significant differences in enforcement styles and intensity across jurisdictions. ${ }^{134}$

In terms of the specifics, as the UK has a long history of influencing the development of securities law as the EU has evolved, it is a jurisdiction that is well placed with the technical expertise required to shape its domestic securities legislation for the future. Next, and drawing on the paper's earlier analysis, the UK regulator could consider reframing some of the more deregulatory aspects contained within the new EU prospectus regime, including those geared towards making prospectuses more consumer-friendly. In particular, as it has been demonstrated that retail investors are unlikely to read or understand the documentation ex ante, and as any such investors will be protected indirectly by the mechanism of full and mandatory prospectus disclosure, future UK rules could be geared towards guaranteeing that the prospectus is as valuable an information tool as it can be for sophisticated market participants. For example, where an IPO takes place, this refashioning exercise could seek to ensure that a prospectus contains all the requisite information items that are deemed relevant and necessary by sophisticated market participants in order for them to accurately price the shares that are on offer, rather than, as Enriques articulates 'working out the information needs of a mythological non-professional prospectus reader'. ${ }^{135}$ Indeed, given that rational investors are the parties making informed decisions ex

${ }^{132}$ Eilis Ferran, 'The UK as a Third Country Actor in EU Financial Services Regulation' (n 12). In this regard see also, IOSCO, Objectives and Principles of Securities Regulation (2017).

${ }^{133}$ The literature in this area focuses especially on cross-listings in the US but note that the 'bonding hypothesis' is considered to be of particular relevance to issuers whose home regimes have weaker securities laws, see John Coffee, 'Racing Towards the Top? The Impact of Cross-Listings and Regulatory Competition on International Corporate Governance' (2002) 102 Columbia Law Review 1757.

${ }^{134}$ See further John Armour, Martin Bengtzen and Luca Enriques, 'Investor Choice in Global Securities Markets' (ECGI Working Paper No 371/2017). See also e.g. Howell E Jackson and Eric Pan, 'Regulatory Competition in International Securities Markets: Evidence from Europe - Part II' (2008) 3 Virginia Law \& Business Review 207 (discussing that issuers now have a number of ways to tap the US markets, but also observing that the greater risk of US enforcement can act as a deterrent to foreign issuers).

${ }^{135}$ Luca Enriques (n 11). 
ante about which projects are most deserving of external funding, it is such participants that securities regulation should be most concerned with protecting. ${ }^{136}$

From the issuer's perspective, a gold plated prospectus regime could also produce greater legal protection to reputable firms who take the time, effort, and go to the expense of fully complying with a higher regulatory burden ex ante (also thereby enabling market participants to draw their own conclusions about any issuers making lesser disclosures). This could help to guarantee that prospectuses are accurate ex ante, and also assist in protecting trustworthy firms against the threat of subsequent public enforcement, or civil litigation ex post, an issue likely to be accentuated today and going forward, given the easier access to the UK courts for investors.

Of course, stumbling blocks exist, and others should be anticipated. First, the new EU prospectus regime is being implemented in the form of a regulation precisely to ensure its uniform application in practice. In line with the observations in section 5.1, this could suggest that ESMA and the Commission might look rather unfavourably on an UK bespoke regime that does not follow the EU rules to the very letter. Yet, on the other hand, for the Commission to draw the conclusion that a super-equivalent UK regime did not meet the EU's equivalency criteria could 'strain the credibility of commitments to avoid legalism'. ${ }^{137}$ There is a related issue; an equivalence-plus approach could end up producing a 'regulation-heavy' regime. This is true, but perhaps the driver of the UK seeking to assure its continued international competitiveness could help to manage any such risks. ${ }^{138}$

Linked to this issue, a new UK/EU issuer disclosure relationship could also be envisaged. The precise nuts and bolts of this is beyond the scope of this paper, but in general terms such a set-up could be based on the long-established multijurisdictional disclosure system ('MJDS') adopted by the US'S SEC and the Canadian provincial securities regulators (a regime that has been described in legal scholarship as 'equivalence-plus'). ${ }^{139}$ In brief, the MJDS is a reciprocal arrangement that enables eligible Canadian issuers to publicly offer securities in the US and vice versa, with the more common scenario involving a Canadian firm making a public offer in the US. In such a situation, a prospectus (termed a registration statement) is largely prepared and reviewed in accordance with Canadian disclosure requirements, but such firms are also required to then supplement their registration with certain additional disclosures;

\footnotetext{
${ }^{136}$ See Goshen and Parchomovsky (n 47) (although expressing such sentiments particularly with respect to the secondary markets).

${ }^{137}$ Eilis Ferran, 'The UK as a Third Country Actor in EU Financial Services Regulation' (n 12). Note that the Prospectus Regulation wording contains a straight equivalence test in article 29. As Ferran articulates, the position with such a test is less clear than where the relevant wording provides that third country requirements be 'at least' equivalent to EU provisions.

138 Ibid.

139 See e.g. Tzung-bor Wei (n 107). See also Hal S. Scott, 'Internationalization of Primary Public Securities Markets' (2000) 63 Law and Contemporary Problems 71 who categorises the MJDS as an example of mutual recognition. Note that it is recognised that the MJDS has not been without its problems, see J. William Hicks, 'Harmonization of Disclosure Standards for Cross-Border Share Offerings: Approaching an "International Passport" to Capital Markets?"' (2002) 9 Indiana Journal of Global Legal Studies 361. It is also acknowledged that there are arguments that the impact of institutionalisation and globalisation can render such bilateral agreements otiose, see John Armour, Martin Bengtzen and Luca Enriques (n 134).
} 
and US liability rules continue to apply in the main. ${ }^{140}$ Such a framework may be useful to reflect on in the context of a future UK/EU arrangement (including whether such a formalised framework is in fact necessary or whether market-based solutions may suffice), although careful consideration would need to be given to the linked questions of oversight, and enforcement, including whether an independent dispute resolution system would be necessary to ensure conformity with a new system. ${ }^{141}$

One way or other, it also remains true that any UK model which proposes further rather than fewer regulations is unlikely to go down particularly well with politicians and others who champion a more relaxed, Singapore-on-Thames scenario. Nonetheless, this paper speculates that, legally, a super-equivalent regulatory regime could best serve the UK over the longer term. From a pragmatic standpoint, it should ensure that the UK's provisions are most likely to be considered equivalent for the purposes of the EU's third country assessment criteria. More generally, however, and by analogy with the UK's current goldplated premium listing rules, such a stance could assist in bolstering the UK's reputation as an IPO location in which investors trust; a high-calibre jurisdiction with a strong legal system, and a reputable 'brand', facilitated, in part, by its super-equivalent regime. ${ }^{142}$

\section{Conclusion}

Although the on-going geopolitical uncertainty and the unpredictability surrounding the Brexit negotiations may inhibit capital markets-based activity in the UK in the short term, ${ }^{143}$ a recent survey suggested that many investors remain confident that Brexit may create opportunities despite the uncertainty. ${ }^{144}$ Accordingly, this article has sought to inject a note of optimism amidst the pessimism surrounding the Brexit fallout, and to contribute to the existing legal scholarship on prospectuses by exploring what could happen to the UK's prospectus regime going forward, based on the likelihood that the UK will exit the single market. Via an analysis of the theoretical foundations behind the mandatory disclosure requirements, and through a critique of two of the deregulatory aspects of the new EU reforms, this paper then reflects on possible policy avenues for a future prospectus framework for the UK. Although the avenues of pure equivalence, or a bonfire of red tape are possibilities, the paper speculates that the UK could, and should, consider embarking upon a distinct regulatory path of super-equivalence. This would likely meet the EU's rather nebulous equivalence criteria, but, crucially, also help to guarantee the UK's reputation as an esteemed and leading capital market for the foreseeable future.

\footnotetext{
${ }^{140}$ Tzung-bor Wei (n 107). The key exception to the applicability of US liability rules is that a registration statement will not be considered misleading or fraudulent simply because it does not contain the information required by US rules, see Hal S. Scott (n 139).

${ }^{141}$ Niamh Moloney, 'Negotiating a Financial Services Deal' (n 103).

${ }^{142}$ See e.g. Financial Conduct Authority, Review of the Effectiveness of Primary Markets: The UK Primary Markets Landscape: Discussion Paper 17/2; Financial Services Authority, The Listing Review and Implementation of the Prospectus Directive - Draft Rules and Feedback on CP 203 (Consultation Paper 04/16).

${ }^{143}$ Charles Howarth (n 104).

${ }^{144}$ PricewaterhouseCoopers, IPO Watch Europe Q2 2017 (July 2017).
} 
Acceptance Version: March 2018 European Company and Financial Law Review 